\title{
Theoretical Perspectives on Campus Cultism and Violence in Nigeria Universities: A Review and Conceptual Approach
}

\author{
Amos Emiloju Arijesuyo (Ph.D) \\ Head, Guidance and Counselling Unit \\ Federal University of Technology, Akure, Nigeria \\ Tel: 234-80-3585-6299Ｅ-mail: arijesuyoamos@yahoo.com \\ Oyewole Omoniyi Olusanya (Corresponding author) \\ Department of Sociology, University of Ibadan \\ Ibadan, Nigeria \\ Tel: 234-80-3386-1136 E-mail: oyewole.olusanya@yahoo.com
}

Received: November 12, $2010 \quad$ Accepted: December 19, $2010 \quad$ doi:10.5539/ijps.v3n1p106

\begin{abstract}
Most African universities including Nigeria have witnessed youth violent activities laced with campus confraternities. The disturbing phenomenon has led to several theories on the emergence of this worrisome trend and what could be done to stave it off. This paper reviewed the major theoretical perspectives on the campus cult-violence and its attendant psychopathological behaviour among Nigerian youths. The review is selective and confined to the theoretical and investigative perspectives which presumably best fit Nigerian models of socio-cultural background. In the light of the existing empirical research which bears upon these theoretical conclusions; a conceptual framework - psycho-infrastructuralism was proposed as an intervention model. The framework shows the linkages between campus cult-violence and key factors of psycho-personality bias, frustration-aggression hypothesis, ethno-political theory and the environmentalist perspectives. It is suggested that, as a complex dynamic process, campus cult-violence activities and its key covariates must be measured and analyzed within psycho-infrastructural model.
\end{abstract}

Keywords: Nigerian confederation, Ethnic militias, Psycho-personality theory, Frustration-aggression hypothesis, Political oppression, Psycho-infrastructural model

\section{Introduction}

Violence is typified by an act of aggression, brutality and unfriendliness. It could be cruel and sadistic. When it is physical (not all violent acts are physical) it could end up in bloodshed and destruction of properties. It is an antonym of Peace and Calmness. In recent times, Nigerian society and indeed other African countries have witnessed an increasing trend in the scope and sophistication of youth immorality and violent antisocial acts. The situation appears worrisome as it escalates by the day. Ordinarily, this state of affairs should be seen as indicators of the socio-economic and political state of affairs of most developing African states in the past two decades or so. But what we have found more disturbing is its permeation into the structure of our educational institutions including the primary and secondary schools!

\subsection{Campus Cult and Violence in Nigeria}

Tertiary institutions in Nigeria are expected to play a major role in the country's human resources development and to serve as vibrant centres of productive research and academic excellence. At the moment, cult violence has become a serious bane among tertiary institutions in Nigeria; and intensely so in the last two decades. Nigerian University campuses are not spared from the vestiges of crime rocking the national scene by ethnic militant groups such as Oodua People's Congress (OPC), Arewa People's Congress, Egbesu Youths, Bakkassi Boys; and lately the Niger-Delta militants. Quite unfortunately too, the university is the major critical target point where the bulk of adolescent offenders are either students or stakeholders who constitute the high risks and also pose challenges to institutional managers who are at the receiving ends of youth violence and psycho-pathological carnage in our 
university campuses. Most of the extant literatures that have ventured to study the phenomenon have been preoccupied mainly with magnifying the implications of secret cult activities in Nigerian universities which includes youth carnage on campuses commonly referred to as cult wars, thuggery at political events/activities, motor parks "overthrows", rivalry for the same girl/woman referred to as macho-violence, gang rape, drug-related violence, assault on life and properties, indiscriminate use of light weapons, dangerous arms, and the resultant disruption of academic calendar(Gbolahan,2003)

Unfortunately, efforts made to curb the menace of secret cults in tertiary institutions in particular, and the society at large, have so far yielded very little or no results. This is in spite of decree 47 of 1989, which provides for a five-year jail term for anyone belonging to campus cults. Thus, cultism remains a veritable social menace and a serious obstacle to peace and harmony in many tertiary institutions in Nigeria. Although some university authorities, through administrative panels of inquiries, have suspended or rusticated some students for participation in cult-related activities and violence, on the whole, secret cults have proved difficult to eradicate. In fact, it is commonly believed that solutions to campus cult violence are difficult to come by because findings have shown that highly placed university staff and other prominent members of the society, are known to belong to secret cults, and often serve as "god fathers" to these young cult members (Olabisi et. al.2003).

Individuals, groups and governments have of late expressed concern over the problem through the mass media. State and Federal authorities have also adopted other measures to tackle the problem through prosecution and imprisonment of cult members, rustication of cultists from colleges and publishing their names in national dailies among others. However, these measures are akin to a "fire brigade's" responses to a fire outbreak; they are transient and have so far failed to provide a lasting solution to the nefarious activities of campus cults. In fact, research findings have shown consistently high and unabating increase in the number of Nigerian undergraduates who are being rusticated from the universities because of cult-related activities. Authoritative source from a study conducted by (Ibn-Godidi; 2008) confirmed that an average total of 23,650 Nigerian undergraduates were indicted of cult-related offences and were either suspended or rusticated from the university between 2001 and 2008 .

While most theoretical perspectives reviewed (Adelola, 1997; Elegbeleye, 1997; Tamuno,1999) have offered testable hypothesis which if appropriately applied; appear useful in explaining the phenomena of campus cult-violence and its associated psychopathological challenges in Nigerian university campuses, the major flaws of these previous efforts is that,(i)they have been mainly descriptive in nature,(ii)lack comprehensive theoretical framework with the inherent tendency of over-simplifications of ideas and(iii) the apparent tentative or inconclusive nature of their submissions. Operating from the premise that, the complex multi-variates phenomena of campus cultism and violence could not be explained in terms of discrete independent variables per se, the present review have drawn conclusions by examining varieties of available research evidences in a way to analyze campus-cult violence as a multi-dimensional social problem. This view has been corroborated by Uguru-Okorie (2001) and Arijesuyo (2010) who maintained that since man is a product of a complex interactive forces of his psycho-personality constructs and his environment, proper understanding of the phenomenon of violent campus cult and the attendant anti-social behaviour among Nigerian youths requires the construction of appropriate conceptual models which have greater explanatory value and analytical power than the previous descriptive works.

This underlying assumption is therefore predicated on the fact that, until such conceptual models are constructed, there will be no general agreement about the explanatory value of scientific and theoretical perspectives on the subject of campus cult and its associated social vices prevalent among Nigerian undergraduates. Again, the key components of the conceptual framework would need to be adequately measured for hypotheses testing as a means of expanding the frontiers of knowledge on the subject matter for future researchers.

\section{Theoretical Perspectives}

Although most studies on campus cultism and destructive behaviour among Nigerian undergraduates lack a comprehensive theoretical framework, several hypotheses emerging from previous works can be considered as theoretical perspectives for future research. These theoretical approaches can be sub-divided into four broad categories:

(i) Ethno-Political Theory (ii) Psycho-Personality Perspectives (iii) Frustration Aggression Hypothesis (iv) Environmentalist Perspectives.

\subsection{Ethno-Political theory}

The proponents of this theory emphasize the role of political structure and multi-ethnic diversity of the Nigerian state as a key factor in explaining youth revolutionary tendencies and the attendant violent behaviour. While providing philosophical foundation for this hypothesis, Marcel (2008) noted the pluralistic nature of 
ethno-political structure of Nigeria state before the emergence of new Nigerian confederation which he described as "a state of nations and nationalities characterized with multi-cultural, multilingual and multi-religious society with differing socio-economic and political systems."

The effect of these multi-diversities on the national integration and the contending forces of polarization of socio-economic and political affiliation along ethnic dimension had frequently ridden the political atmosphere of the nation with youth violence and revolutionary behaviours in the last few decades. Emerging trends have shown that the associated carnage and destructions perpetrated by the ethnic militias under the aegis of the different confraternities; whose activities have resonance beyond the immediate societies to the nation's university campuses. In support of this assertion, Marcel (2008) noted that the inability of the political leaders in galvanizing the multi-ethnic and pluralistic nature of socio, economic, political and natural endowments of the Nigerian state are indicative of the opposing tension in the forces of integration vis-à-vis the forces which are pushing for devolution, regionalism and fragmentation.

According to this school of thought, the emergence of the different ethnic militia groups such as the Oodua Peoples' Congress (Yorubas of South-West), Arewa Peoples' Congress (Hausas of the North), Egbesu Youths (Ibos), the Bakkasi Boys (Bayelsa) and the Niger Delta Militants (South-South States) were fundamentally motivated to engage state security agents in the quest to control the resources that come from their region and to canvass for fair treatment and equity among the states of the federation. (Marcel, 2008).

Many researchers who wrote from the historical perspectives argued that, youth violent activities in the pre-colonial Nigeria were positively associated with nationalistic movement and the need for political emancipation of the Nigerian state from the vestiges of its colonial imperialist (Anya, 2002). In line with this hypothesis, Ibn-Godidi (2008) maintained that, what is generally referred to as campus cult and youth violence today began as a "constructive violence" to protest against the a normally and sense of injustice perpetrated by the colonial opportunists. Expatiating further on this tradition, the historical antecedents of campus cultism and violence in the nations' universities was linked with the formation of Pirates confraternity a.k.a. National Association of Sea Dogs, founded by Professor 'Wole Soyinka and six others popularly known as G7 in 1952 (Adewole, 2005). An authoritative source which derives from the treatise of Marcel (2008) asserted that, pyrate confraternity was formed with a "mission of political emancipation" largely to protest against the colonial vestiges on the Nigerian university system as well as fight against oppression, injustice and to restore social order as cardinal mission of the political reconstruction of the Nigerian state.

Qualitative historical report on the above assertion by Ibn-Godidi (2008), further maintained that, the overwhelming popularity and acceptability of the nationalistic mission-goals of the founding fathers of the Pyrates confraternity provided the building blocks and the motivational impetus for the nationalistic movements among the literate Nigerian youths, who eventually championed the course of Nigeria independence in 1960. Arising from this historical development coupled with the precipitating social-economic and political challenges, the pyrates confraternity soon became a rallying point for the emergence and coalition of other successive of confraternities in Nigeria university campuses. Prominent among them are the Buccaneers a.k.a. Buccaneer Association of Nigeria (BAN), Black Axe a.k.a. Neo-Black Movement of Nigeria, Vikings, Mafite, Eiye, Black Berret, etc. While historical analysts (Ibn-godidi 2008, Marcel, 2008) share consensus on this tradition, Adebayo (2001) however noted that, what is perhaps worrisome is that the grand ideas which informed the formation of the confraternities have long been abandoned by many of these groups, stressing that values other than being altruistic have become the "driving force". Contrary to the laudable objectives of their founding fathers, the campuses were turned into theatre of warfare where "primordial rivalries among groups and reprisal attack with display of dangerous and sophisticated weapons are freely totted on the campuses" (Adebayo;2001). Adiamoh (2003) while corroborating the above assertion noted that the original aims and noble tradition of the nascent group were later twisted by some evil minds and vehemently maintain that the original confraternity did not swear any secret oath of allegiance, or any blood covenant.

\subsection{Psycho-Personality Perspectives}

Psychologists have emphasized the influence of innate tendency (drives) in human, which have a natural and compelling tendency towards violence and destructiveness. In line with this tradition, Freud (1923 quoted in Uguru-Okorie 2001), proposed a structural model of personality which consists of id, ego and the superego. For purpose of this paper, our focus will be on id. Freud proposed that the human drives (instincts) reside in the id and operate from there. The source of human psychic energy which is the origin of aggressive drive in human also resides in the id. (Freud; 1923, Uguru-Okorie, 2001)

The Freudian psycho-personality theory led to the formation of a variety of hypotheses about the psychological 
perspectives of human violence and destructive behaviour. Hoffling (1975) for example, reviews the phenomena in human society which suggest support for Freudian view, that there exists in humans a basic drive that finds expression in violence and destructiveness. Thus, the phenomena of wide-spread international and intra-national hostilities, the ever-rising incidence of crime and delinquencies which include armed robbery, assassination, ritual killings, kidnapping, and secret-cult activities could partly be explained in terms of this theoretical standpoint. Hoffling (1975) therefore concluded that, "no species other than human fights, injure and kills its own kind so persistently or on so large a scale (Hoffling; 1975 p. 58).

Quite a reasonable theoretical and empirical studies (Adelola, 1997; El-kenz, 1996) share common ground from the early Freudian psycho-personality hypothesis for explaining the phenomenon of campus cult, violence and crimes in Nigeria. However, a few other recent scholars (Olabisi et al., 2003; Mercel (2008) have further established positive relationship among human psycho-personality factors and the potential interactive forces of social-cultural variables and thus suggested that campus cultism in Nigeria is indicative of deeper psychological trauma; a crisis of identity that is pervasive among youths today. This trauma, according to this prescription, predisposes youths, especially those who were denied early parental affection through broken homes; and others who grew from their early childhood years in foster homes, boarding nursery/primary school through secondary schools, and consequently had suffered denial of parental affection with attendant behaviour disorder. The psychological deficit of marginalization and exclusion from early parental warmth and protection normally leads to socially deficit behaviour among youths, especially their involvement in campus cults and huge appetite for gang violence as evidenced of acute personality disorders internalized from the subconscious early years. It is therefore not surprising to find that adolescents and young adults who are supposed to be leaders of tomorrow form the bulk of perpetrators of crime and social vices in the society. Animashaun (2004) reported that adolescents with personality disorders constitute $80 \%$ of convicted and incarcerated prison inmates for various personality disorders-related offences ranging from rape, cultism, robbery, thuggery, kidnapping to man slaughter in his study area in Agodi Ibadan Prison, Nigeria.

\subsection{Frustrations- Aggression Hypothesis}

The main assumption of this hypothesis is that violence becomes a defence mechanism strategy when it becomes apparent that means of satisfying pressing human needs are being denied. This could take the form of bio-social and economic denials. Frustration- aggression hypothesis as basis for explaining human motivational state, and destructive pattern of response as a mode of behaviour, has been elaborated by Uguru-Okorie (2001) and Gbolahan (2003). These authors state emphatically that "the occurrence of aggressive behaviour always presupposes the existence of frustration and contrariwise, that the existence of frustration always leads to some form of aggression. Olabisi et al. (2003) elaborated on this view when they pointed out that, "frustration is displaced elsewhere, usually to some less threatening object or to oneself, when it is impossible or dangerous to direct the aggression toward the frustrating event".

Against this background, it is not difficult to find a link among the social phenomena of crime, cultism and crises in Nigeria's tertiary institutions, particularly in the light of the frustration - aggression hypothesis. An observation of the Nigerian society, particularly of the dying decades of the $20^{\text {th }}$ century and the dawn of the $21^{\text {st }}$ century shows that the society is pervaded with frustrating events and frustrating circumstances, one in which it could be said that frustration is endemic. Since the 1980s, oppression and injustice have been rife, poverty has spread like wild fire, and frustration of the basic needs and aspirations of the vast majority of citizens, including the children and the youth, has been a cardinal feature of our decadent society. One result of widespread and severe frustration of the legitimate needs and aspirations of the masses of Nigerians has been the development in the personalities of ordinary Nigerians of varying degrees of hostile and destructive traits, which manifest, in certain cases, in criminal behaviour, cult membership and sometimes, crises orchestrated by frustrated youths in our universities and colleges. Thus, it may defensibly be asserted that a common denominator shared by the phenomena of cultism, crime and crises in our institutions is the existence of hostile and destructive urges in criminals, secret cult members and ring leaders of violent crises in our higher institutions. As we have seen, this personality trait, characterized by hostility, and destructiveness, can be traced back to early experiences of frustration, and such experiences come from the environment.

It is also interesting to note that, the specific events that trigger violent crises in our universities and colleges are usually the particular environment of a given institution, and can often be seen to involve the frustration or denial some basic needs or aspiration (or set of these) of the whole student population or some vocal or otherwise significant subset thereof (i.e. the High-Risk). The frustration might be associated with inadequate accommodation facilities, unsatisfactory transportation arrangements, poor feeding (where students live as boarders), student union elections, struggle for supremacy between rival secret cult groups on campus and so forth. On the part of staff, the 
precipitating events or circumstances might have to do with the frustration of workers' aspiration for higher pay and improved conditions of service or with other aspects of management-labour relations. Perhaps it is worthwhile to point out in particular that, the unstable academic calendar of public universities in Nigeria, characterized by incessant prolonged strike by the staff unions ASUU, SSANU and NASU to protest against frustrating working environment finds justification for this hypothesis.

\subsection{Environmentalist Perspectives}

The underlying assumptions of the environmentalist hypothesis hinged on the belief that, patterns of behaviour are to a great extent influenced by the prevailing circumstances in the society. To a Biologist and Environmentalist, the concept is by far the rule of nature, which visualizes the concept of variation in species and evolution of new types of behaviour in organisms as a reaction to extreme changes in the immediate environment in which the organism finds themselves. It is simply a reaction to "negative" forces, thus calling for survival strategies (Sarojini; 2007). In this context, it is valid to propose that youth violence as seen today is a product of series of events in the life of our nation over the last two decades or so.The protagonist of environmentalist perspectives assumes that the current level of campus cult and violence results from the breakdown of social, economic and cultural norms of the larger society. Scholars persuaded by this thesis (Olabisi et al; 2003 and Gbolahan; 2003) argue that Nigerian universities mirror the image of a public space that has, since the introduction of SAPs in 1986, collapsed in the face of daunting socio-economic pressures. In this context, cult activities thus become evidence of a relapse of civil morality; the product of a society characterized by exclusion and inequality, and lack of institutional or social control. Under this type of excruciating social reality, students and youths generally, are caught in the "age of anxiety" that forces them to constantly challenge and narrow the wide generation gap that separates them from adults.

In line with this argument Gbolahan, (2003) commented on the excruciating living and learning conditions that students must contend with on a daily basis; including physical, social and psychological environment of learning and concluded that the intellectual space has been stretched to the farthest limit due to dwindling statutory subventions from governments. It therefore becomes much easier for students with anti-social orientations to lure or pressurise their colleagues, especially those on the fringe of expulsion for poor academic performance, to join cult groups. Memberships of secret cults not only give such students a sense of belonging, but also place at their disposal, a veritable instrument of terror and revenge.

\section{Conceptual Framework and Analytical Approaches}

From the theoretical perspectives reviewed above a conceptual framework of psycho-infrastructuralism (Uguru-Okorie, 2001) has been proposed as an intervention model. Uguru-Okorie (2001) developed an approach to the understanding and control of behaviour which rests on the assumption that it is possible by regulating relevant environmental factors, to regulate actions and whole patterns of behaviour. The operational processes of psycho-infrastructural manipulation involves the stimulation, facilitation, channelling or hindering of a given behavioural outcome. This order of environmental manipulation is the cardinal contribution of psycho-infrastructuralism to the science and art of behavioural control, and indeed of behaviour modification. Uguru-Okorie, (2001) further asserted that, environmental manipulation not only has the potential of determining the forms of immediate behavioural expression, but also produces in individuals the internalization of the compelling dictates of the environment and the fostering of values consistent with behaviour favoured by the environment as manipulated (p.5)

Values on the other hand may be categorized into terminal values (preferred state of affairs) and instrumental values (preferred modes of behaviour) (Okolie,.2003;Ezeilo 2003) In this classification, terminal values are reminiscent of Uguru-Okorie (2001) definition of values as stimulus events that an organism would preferentially work for, whereas adjectival or instrumental values agree closely with Bandura (1992) definition of values in terms of those responses that an organism would preferentially emit in the face of possible alternatives. In either case value is directly or indirectly defined in terms of behaviour. Thus, value can be influenced from three sources, as follows: environmental manipulation, behavioural change and the desired state of affairs. Finally, behavioural change that produces a desired state of affairs is reinforced by this outcome according to simple instrumental conditioning principles, and receives support from value change that is consistent with the desired state of affairs and with the behaviour in question.

According to this model (Fig. 1), relevant changes in the environment produce behavioural change. Where the resulting behavioural change leads to a desired state of affairs, the outcome is some kind of value change. Such a behavioural change is usually associated with value change. Independent programmes of environmental manipulation can also be mounted to directly produce value change. 
In applying this model to change behaviour and value re-orientations to achieve a desired state of affairs, a careful analysis is made of the environment and all possible behavioural options and values. The desired state of affairs is also determined. Then deliberate changes are introduced into the environment on the basis of the analysis that has been made. The environmental changes are carefully selected for relevance and efficacy in bringing about changes in behaviour that will produce the desired state of affairs. Such changes in behaviour being associated with a desired state of affairs will lead to value change in a direction consistent with the desired state of affairs and the behaviour producing it. Furthermore, the desired state of affairs reinforces the behaviour producing it, and value helps maintain behaviour in the desired direction.

\section{Summary and Recommendations}

Despite the divergence views and hypotheses postulated by the various theoretical standpoints reviewed on the phenomenon campus cultism and violence in Nigeria, a striking feature of consensus is that, the environment in our educational institutions and indeed the socio- economic and political atmosphere of the national life is ridden with frustrations and appears to be potentially laden $t$ with strife and crises. In most institutions in Nigeria the learning environment is fraught with a situation where basic needs of staff and students are not met. Accommodation and transportation arrangements are inadequate. Infrastructural provisions are very poor. Electricity is virtually non-existent as far as the needs of the laboratories, libraries, classrooms, hostels and offices are concerned. Water supply is unreliable even for such basic needs as drinking, washing and flushing the toilets, not to talk of the requirements of the laboratories. Chemicals and materials are not available in the laboratories. Books and journals are not available in the libraries in the right quality and quantity. Lecturers are not equitably remunerated or duly respected and many eke out their livelihood by selling "handouts" sometimes in a shameful exploitation of the innocent and hopeless students. The cry of inadequate funding of these institutions appears to go perennially unheeded by the proprietors, and management in these institutions is not given room to do much more than manage poverty. Salutary recreational facilities are dwindling where they have been put in place in the past, and in other places are virtually non-existent. Moreover, general indiscipline and loss of desirable values in the larger society has not spared the institutions. In and outside our universities and colleges, the idols in vogue are power and money, and most persons worship either or both. Power and money rule, at the expense of law. Hence, there is no guarantee that the law will take its course if a criminal, cultist or fomenter of strife or thief and bloody demonstration happens to be powerful and rich or to be a ward of somebody powerful and rich.

Practical application of psycho-infrastructural model in dealing with the problems of youth violence and campus cultism in educational institutions will obviously involve the following processes: (i) analysing the institutional environment in Nigeria, and/or particularly in any specific university or college in focus, (ii) correction of identified anomalies in the environments of tertiary institutions in Nigeria (environmental manipulation) and (iii) deliberate promotion and inculcation of value re-orientation(desired state of affairs) among the youths through appropriate programme and role modelling of the adult class. If these anomalies are corrected and deliberate measures geared towards the modification of behaviour, crime will be reduced and cultism stamped out, and the incidence of crises in our campuses.

\section{References}

Adebayo, W. (2001, July 8). VCs use secret cults to settle scores. Sunday Punch, pp.1-2

Adelola, I.O.A. (1997). Campus cults and the mass media. In O.A. Ogunbameru (ed.), Readings on campus secret cults, (pp.132-146). Obafemi Awolowo University Press, Ile-Ife.

Ademola, A. (1998). Students in the age of anxiety and the growth of occultism in Nigerian university campuses: A Re-examination. In O.A. Ogunbameru (ed.), Readings on Campus Secret Cults. (pp. 93-104). Obafemi Awolowo University Press, Ile-Ife.

Adewale, R. (2005). Violence in the Citadel: The menace of secret cults in the Nigerian universities. Nordic Journal of African Studies, 14(1) 79-98

Adiamoh, G. (2003, Jan 12). Our citadel of knowledge, our dens of cults. Sunday Tribune, p. 32.

Animashahun, R.A. (2004). Effect of two creativity techniques in the prevention of social vices in Nigeria. The Counsellor, Volume 20(1) 14-26.

Anya, O.A. (2002). Building the African giant: Managing the dreams, vision and myth of the Nigerian Reality. Management in Nigeria. Nigerian Institute of Management, 5-10.

Arijesuyo A.E., and Adeyoju C.A. (2010). Effectiveness of cognitive restructuring counselling strategy on students' attitude towards examination malpractice: Implications for social re-engineering. Nigerian Journal of 
Applied Clinical \& Counselling Psychology. (In Press).

Bandura, A. (1992). Social learning theory. Englewood Cliffs, Prentice Hall.

Elegbeleye, O.S. (1997). Personality dimension to university campus cult membership. In O.A Ogunbameru (ed.), Readings on campus secret cults, (pp.35-50). Obafemi Awolowo University Press, Ile-

Ezeilo, B.N. (2003). Value orientation and students behaviour. In Okolie A., Students unionism in a democracy (105-113). Enugu.SNAAP press Ltd .

Freud, S. (1923). The ego and the id. New York, Norton.

Gbolahan, O.B. (2003, Nov.19). Youth violence. A paper presented at the workshop on youth violence organized by Centre for Development and Conflict Management Studies (CEDCOMS), O.A.U, Ile-Ife.

Hofling, C.K. (1975). Textbook of psychiatry for medical practice. Philadelphia, Lippincott Company.

Ibn-Godidi. (2008). Axe-man the Neo-Blackis; Uhuru. A Publication of Neo Black Movement of Africa. 25, 35

Ife.

Marcel O. (2008). Eradication of youth violence: A Panacea for African; Uhuru A Publication of Neo Black Movement of Africa, 25, 11-12.

Okolie A. Ezikeojiaku \& Chibiko N.O. (2003). Students Unionism in a Democracy. Enugu, SNAAP press Ltd.

Olabisi, A. Adelanwa, O., Amadu, S., \& Charles, U. (2003). Cultism and youth violence in Nigerian Universities. In Centre for Development and Conflict Management Studies (CEDCOMS) Monograph Series 2(3-67). Ile-Ife, Obafemi AwolowoUniversityPress.

Sarojini, T. R. (2007). Modern Biology for senior secondary schools. Abuja: Africana Publishers Limited.

Tamuno, T.N. (1999). Peace and Violence in Lagos, Nigeria Federal Government Press. p.124.

Uguru-Okorie D.C. (2001, 30 ${ }^{\text {th }}$ May). The psychological dimension of crime, cultism and crises in Nigerian institutions. A Paper presented at a seminar organized for security personnel, University of Ado-Ekiti, Nigeria.

The model

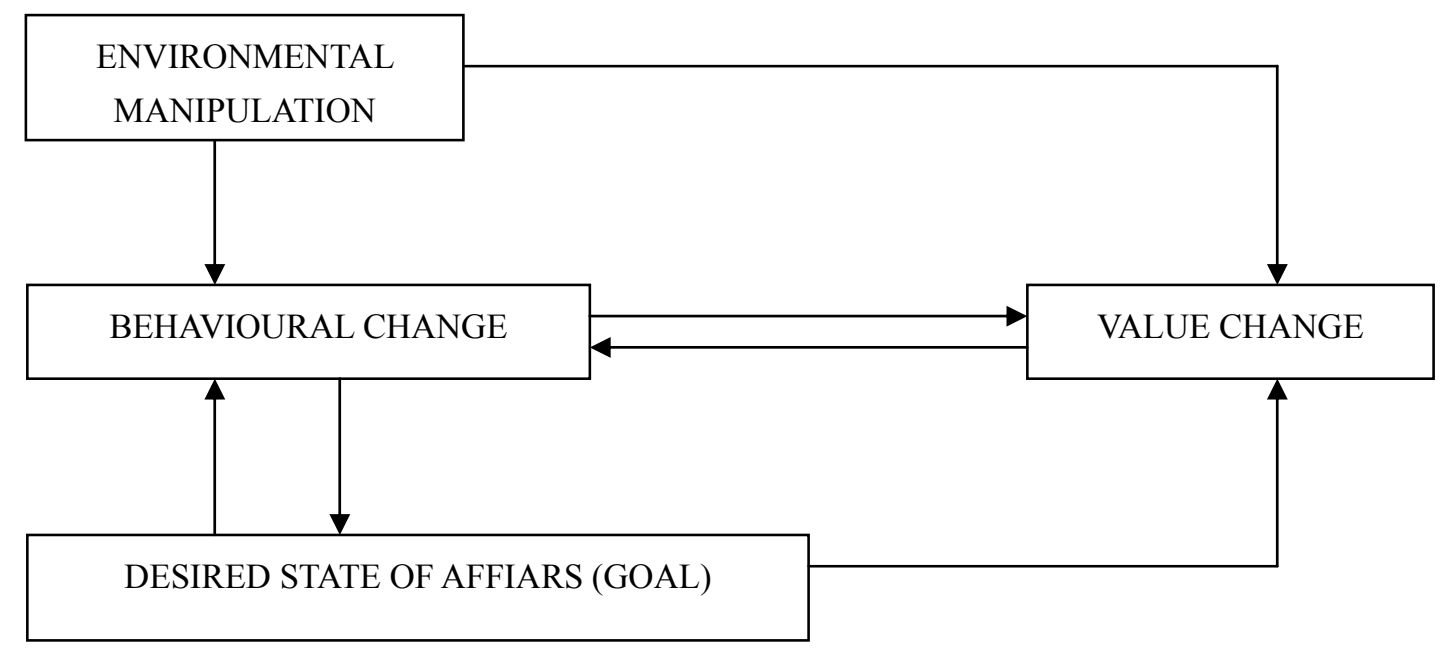

Figure 1. Model of .Psycho-infrastructuralism

Source: Uguru-Okorie; 2001. 